\title{
Evaluation of Green Insecticides against Gram Podborer, Helicoverpa armigera (Hubner) in Pigeonpea (Cajanus cajan L.)
}

\author{
P. Thilagam*", D. Dinakaran and A. Gopikrishnan \\ Tamil Nadu Agricultural University, Agricultural Research Station, \\ Virinjipuram, Vellore, Tamil Nadu, India \\ *Corresponding author
}

\begin{abstract}
A B S T R A C T
\section{Keywords}

Green insecticides, Pigeonpea, Gram podborer, Helicoverpa armigera, Pod damage

Article Info

Accepted:

24 July 2020

Available Online:

10 August 2020

Two field experiments were conducted during Kharif, 2018 and 2019 to evaluate the efficacy of green insecticides against gram podborer, Helicoverpa armigera (Hubner) in pigeonpea in comparison with the sequential application of chemical insecticides. Among the green insecticides tested, Bacillus thuringiensis var.kurstaki@1 g/ litre was found to be effective in minimizing the larval population of $H$. armigera in both the seasons tested. The reduction in larval population resulted in the lowest mean per cent pod damage (23.67) with 47.90 per cent reduction and recorded the highest grain yield of $910.8 \mathrm{~kg}$ per ha with a yield increase of 39.1 per cent over untreated check. However, when compared with the sequential application of insecticides viz., Chlorantraniliprole 18.5 SC $30 \mathrm{~g}$ a.i per ha followed by Flubendiamide 480 SC @ $30 \mathrm{~g}$ a.i per ha and Deltamethrin 2.8 EC@ $12.5 \mathrm{~g}$ a.i per ha the efficacy proved to be second effective treatment which recorded the lowest larval population lead to the lowest mean pod damage per cent with increased grain yield of $1145.7 \mathrm{~kg}$ per ha.

\section{Introduction}

Pigeonpea (Cajanus cajan L.), is one of the most important pulse crops in South Asia. India ranks second in area and production and contribute $90 \%$ of world's pulse production. In India, pigeonpea is grown in 4.42 million ha with an annual production of 2.89 million tonnes with $655 \mathrm{~kg} \mathrm{ha}^{-1}$ of productivity. In Tamil Nadu, it accounts for $1.88 \%$ area $(0.73$ lakh ha) and $3.24 \%$ production (0.91lakh tonnes) with a productivity of $1256 \mathrm{~kg} / \mathrm{ha}$. It is a predominant pulse crop in Vellore district next to groundnut, paddy and sugarcane. It is

grown in an area of 13,584 ha which accounts for about $20 \%$ of the Tamil Nadu state. Though the area under redgram is increasing, the yield remain to be stagnant (500-700 $\mathrm{kg} / \mathrm{ha}$ ) due to insect pest damage. It is attacked more than 250 species of insects, of which podborer, Helicoverpa armigera Hubner is the most dreaded and polyphagous pest of pigeonpea (Shanower et al., 1999). Due to the preference nature of flowering and fruiting parts results in heavy loss up to 60 per cent or sometimes even 80 per cent under subsistence agriculture in the tropics. Management of $H$. armigera relies heavily on
\end{abstract}


insecticides, often to the exclusion of other methods of insect control. At the same time, many insecticides were tested and few of them found to be effective (Yadav and Dahiya, 2004). This resulted in exploration of new alternatives with lesser residues and lower environment threat. One such thing is exploring the opportunities of using ecofriendly insecticides such as Bacillus thuringiensis (Berliner), Beauveria bassiana and NSKE 5\% which can provide alternative, eco-friendly options to control this insect pest (Jeyarani and Karuppuchamy, 2010). Keeping in view, the present study was undertaken to evaluate the field efficacy of green insecticides against $H$. armigera.

\section{Materials and Methods}

Two field experiments were conducted at Agricultural Research Station, Virinjipuram of Vellore district, Tamil Nadu during Kharif 2018 and 2019. The experiment was laid out in a randomized block design (RBD) using Pigeonpea variety $\mathrm{CO} \operatorname{Rg} 7$ with seven treatments and three replications in a plot size of $5.0 \mathrm{~m} \times 5.0 \mathrm{~m}$ with a spacing of $90 \times 30 \mathrm{~cm}$. The crop was raised with recommended agronomic practices. Totally, three sprays were given at 15 days interval commenced from 50 per cent flowering stage using hand operated knapsack sprayer with a spray volume of $500 \mathrm{~L}$ per ha. Observation on the number of larvae per plant was taken at precount, 3, 7 and 10 days after treatment (DAT) in each plot from three randomly selected plants. At maturity, the number of pods showing the damage caused by $H$. armigera were recorded and expressed as per cent pod damage. All the pods from each treatment were then threshed and grain yield per plot was recorded and arrived for hectare.

The data, thus obtained were subjected to RBD analysis using AGRES package (Gomez and Gomez, 1984). Per cent pod damage was calculated by using the following formula
(Naresh and Singh, 1984).

$$
\text { Percent pod damage }=\frac{\text { Number of damaged pods }}{\text { Total number of pods }} \times 100
$$

\section{Results and Discussion}

The results on the larval population of H.armigera in pigeonpea raised during kharif 2018 are presented in Table 1. The data showed that the larval population taken before initiating the spray was non-significant and ranged between 4.44-5.11 Nos. per plant in all the treatments indicating the uniform distribution of larvae. Among all the treatments tested, Chlorantraniliprole 18.5SC @ $30 \mathrm{~g}$ a.i. per ha followed by Flubendiamide 480 SC @ $30 \mathrm{~g}$ a.i. per ha followed by Deltamethrin 2.8 EC @ 12.5 g a.i. per ha treated plots was found to be effective and superior in reducing the larval population and recorded 1.89, 3.33 and 3.40 Nos. per plant at 3, 7 and 10 DAT, respectively. Among the green insecticides tested, Bt var Kurstaki@ $1.0 \mathrm{~g} / 1$ was found effective in reducing the larval population and recorded 3.22, 3.56 and 3.43 Nos. per plant at 3,7 and 10 DAT, respectively. This was followed by entomogenous fungi, Beauveria bassiana @ $5.0 \mathrm{~g} / \mathrm{l}$ recorded with $3.11,3.78$ and 3.85 Nos per plant at 3, 7 and 10 DAT, respectively. The same trend of effectiveness in different treatments was found to be similar with second and third application taken at above intervals. All the treatments tested, were found to be effective in reducing the larval population when compared with untreated check which reported with 5.006.89 Nos per plant throughout the observation period.

The results on the larval population of $H$. armigera in pigeonpea raised during kharif 2019 are presented in Table 2. The precount larval population of $H$. armigera ranged from 3.50-4.40 Nos. per plant. Among the green 
insecticides tested, Bt var Kurstaki@1.0 g per 1 was found effective in reducing the $H$. armigera larvae and recorded 2.31, 1.74 and 1.39 Nos per plant and untreated check reported with 6.64, 5.78 and 5.53 Nos per plant at 3, 7 and 10 DAT, respectively after third application of treatments. The second effective green insecticide, $B$. bassiana recorded with $2.55,2.22$ and 1.66 Nos. per plant. However, the efficacy of the above green insecticides remains second effective treatment when compared with sequential application of insecticides, Chlorantraniliprole 18.5SC @ 30 g a.i. per ha followed by Flubendiamide 480 SC @ 30 g a.i. per ha followed by Deltamethrin $2.8 \mathrm{EC}$ @ $12.5 \mathrm{~g}$ a.i. per ha treated plots and recorded $0.78,0.10$ and 0.22 Nos per plant at 3,7 and 10 DAT, respectively.

The data on the per cent pod damage caused due to $H$. armigera are presented in Table 3. The results revealed that the mean per cent pod damage was low in all the green insecticide treated plots. Among them, the lowest mean per cent pod damage (23.67) with 47.9 per cent reduction and the highest grain yield of $910.8 \mathrm{~kg}$ per ha with a yield increase of 39.1 per cent over untreated check was recorded in Btk @ $1 \mathrm{~g}$ per 1.

The green insecticides treated plots were effective in reducing the pod damage and varied from 23.67-31.33 per cent over untreated check. However, when the green insecticides were compared with chemical insecticides, sequential application of insecticides viz., Chlorantraniliprole 18.5 SC $30 \mathrm{~g}$ a.i per ha followed by Flubendiamide 480 SC@30 g a.i per ha and Deltamethrin 2.8 EC@ $12.5 \mathrm{~g}$ a.i per ha recorded the lowest larval population which resulted in the lowest mean pod damage per cent with increased grain yield of $1145.7 \mathrm{~kg}$ per ha. The expected efficacy of microbial formulations of bacteria and fungi over chemical insecticides in the present studies was not observed to a greater extent probably due to lack of high humidity conditions in field required for the growth of the microbes. The relative low efficacy of the biopesticides over synthetic insecticides in the present findings was also reported by Ankali et al., (2011) who reported that cent per cent mortality of $M$. vitrata larvae at 7 DAT, whereas B. thuringiensis and NSKE showed only 70 per cent mortality. Likewise, Sushilkumar Chauhan and RoshanLal (2009) observed that lower pod damage due to $H$. armigera was recorded in endosulfan than B.thuringiensis var. kurstaki in pigeonpea. Jayashri et al., (2008), Mohapatra and Srivastava (2008), Singh and Yadav (2006) and Gundannavar et al., (2004) also found that per cent pod and grain damage due to $H$. armigera at harvest was the lowest in spinosad and reported that all the chemical insecticides were superior over the biopesticides with high yield and benefit:cost ratio.

Likewise, Sreekanth and Seshamahalakshmi (2011) reported that the per cent in florescense damage due to legume podborer was lowest in spinosad 45\% SC @ 73 ga.i per ha $(4.74 \%)$ followed by $B t @ 1.5 \mathrm{~kg}$ per ha (10.52\%) and B.bassiana @ 300mg per 1 (14.15\%) with 80.9, 57.6 and 42.9 per cent reduction.

The two biopesticides viz., B.thuringiensis and Metarihizium anisopliae were moderately effective while botanical pesticide, neem fruit extract was ineffective. Minja et al., (2000) reported that neem extract and $B$. thuringiensis were not as effective as the synthetic insecticides. In contrast to the present findings, Mohapatra and Srivastava (2008) also reported that $B t$ provided good protection and registered significantly lesser incidence of $M$. vitrata larvae and higher yield. Kulat and Nimbalkar (2000) reported that $B t k, B t k$ alternated with endosulfan alone was the most effective in the reduction of larval population of $H$. armigera. 
Table.1 Evaluation of green insecticides for the management of Gram podborer, H. armigera in Pigeonpea (Kharif 2018)

\begin{tabular}{|c|c|c|c|c|c|c|c|c|c|c|c|}
\hline \multirow[t]{3}{*}{ Treatments } & \multirow{3}{*}{$\begin{array}{l}\text { Dose } \\
\text { per litre }\end{array}$} & \multicolumn{10}{|c|}{ No. of larvae per plant } \\
\hline & & \multicolumn{4}{|c|}{ I spray } & \multicolumn{3}{|c|}{ II spray } & \multicolumn{3}{|c|}{ III spray } \\
\hline & & $\begin{array}{l}\text { Preco } \\
\text { unt }\end{array}$ & 3DAT & 7 DAT & $\begin{array}{l}10 \\
\text { DAT }\end{array}$ & 3DAT & 7 DAT & $\begin{array}{l}10 \\
\text { DAT }\end{array}$ & 3DAT & 7 DAT & $\begin{array}{l}10 \\
\text { DAT }\end{array}$ \\
\hline $\mathbf{T}_{1:}$ Bt Kurstaki & $1.0 \mathrm{~g}$ & 5.11 & $\begin{array}{c}3.22 \\
(1.79)\end{array}$ & $\begin{array}{c}3.56 \\
(1.88)\end{array}$ & $\begin{array}{c}3.43 \\
(1.85)\end{array}$ & $\begin{array}{c}2.56 \\
(1.60)\end{array}$ & $\begin{array}{c}3.11 \\
(1.76)\end{array}$ & $\begin{array}{c}3.22 \\
(1.79)\end{array}$ & $\begin{array}{c}2.56 \\
(1.58)\end{array}$ & $\begin{array}{c}1.78 \\
(1.32)\end{array}$ & $\begin{array}{r}1.22 \\
(1.10\end{array}$ \\
\hline $\mathrm{T}_{2}:$ Beauveria bassiana & $5.0 \mathrm{~g}$ & 4.44 & $\begin{array}{c}3.11 \\
(1.76)\end{array}$ & $\begin{array}{c}3.78 \\
(1.94)\end{array}$ & $\begin{array}{c}3.85 \\
(1.96)\end{array}$ & $\begin{array}{c}3.22 \\
(1.79)\end{array}$ & $\begin{array}{c}3.22 \\
(1.79)\end{array}$ & $\begin{array}{c}3.35 \\
(1.83)\end{array}$ & $\begin{array}{c}3.00 \\
(1.72)\end{array}$ & $\begin{array}{c}2.22 \\
(1.48)\end{array}$ & $\begin{array}{r}1.78 \\
(1.32\end{array}$ \\
\hline $\mathbf{T}_{3}:$ Metarhizium anisopliae & $5.0 \mathrm{~g}$ & 5.00 & $\begin{array}{c}3.67 \\
(1.91)\end{array}$ & $\begin{array}{c}4.11 \\
(2.03)\end{array}$ & $\begin{array}{c}4.23 \\
(2.06)\end{array}$ & $\begin{array}{c}3.33 \\
(1.82)\end{array}$ & $\begin{array}{c}3.33 \\
(1.81)\end{array}$ & $\begin{array}{c}3.68 \\
(1.92)\end{array}$ & $\begin{array}{c}2.78 \\
(1.65)\end{array}$ & $\begin{array}{c}2.11 \\
(1.44)\end{array}$ & $\begin{array}{r}1.56 \\
(1.23\end{array}$ \\
\hline $\mathbf{T}_{4:}$ Lecanicilium lecanii & $5.0 \mathrm{~g}$ & 5.11 & $\begin{array}{c}3.33 \\
(1.82)\end{array}$ & $\begin{array}{c}4.11 \\
(2.02)\end{array}$ & $\begin{array}{c}4.40 \\
(2.10)\end{array}$ & $\begin{array}{c}3.33 \\
(1.81)\end{array}$ & $\begin{array}{c}3.33 \\
(1.81)\end{array}$ & $\begin{array}{c}3.73 \\
(1.93)\end{array}$ & $\begin{array}{c}3.22 \\
(1.78)\end{array}$ & $\begin{array}{c}2.78 \\
(1.65)\end{array}$ & $\begin{array}{c}2.22 \\
(1.46\end{array}$ \\
\hline$T_{5}:$ Azadirachtin 1500 ppm & $5.0 \mathrm{ml}$ & 5.56 & $\begin{array}{c}3.89 \\
(1.97)\end{array}$ & $\begin{array}{c}4.00 \\
(2.00)\end{array}$ & $\begin{array}{c}3.93 \\
(1.98)\end{array}$ & $\begin{array}{c}4.22 \\
(2.05)\end{array}$ & $\begin{array}{c}4.22 \\
(2.05)\end{array}$ & $\begin{array}{c}4.50 \\
(2.12)\end{array}$ & $\begin{array}{c}3.22 \\
(1.77)\end{array}$ & $\begin{array}{c}2.00 \\
(1.39)\end{array}$ & $\begin{array}{r}1.78 \\
(1.31)\end{array}$ \\
\hline $\begin{array}{l}\mathrm{T}_{6:} \text { Chlorantraniliprole } 18.5 \mathrm{SC} \\
30 \mathrm{~g} \text { a.i/ha >Flubendiamide } 480 \\
\text { SC @ } 30 \mathrm{~g} \text { a.i/ha> dimethoate }\end{array}$ & - & 5.00 & $\begin{array}{c}1.89 \\
(1.37)\end{array}$ & $\begin{array}{c}3.33 \\
(1.82)\end{array}$ & $\begin{array}{c}3.40 \\
(1.84)\end{array}$ & $\begin{array}{c}1.78 \\
(1.33)\end{array}$ & $\begin{array}{c}2.33 \\
(1.52)\end{array}$ & $\begin{array}{c}2.40 \\
(1.55)\end{array}$ & $\begin{array}{c}0.56 \\
(0.74)\end{array}$ & $\begin{array}{c}0.00 \\
(0.54)\end{array}$ & $\begin{array}{r}0.22 \\
(0.42\end{array}$ \\
\hline $\mathbf{T}_{7}:$ Untreated check & - & 5.00 & $\begin{array}{c}5.78 \\
(2.40)\end{array}$ & $\begin{array}{c}6.44 \\
(2.54)\end{array}$ & $\begin{array}{c}6.50 \\
(2.55)\end{array}$ & $\begin{array}{c}6.89 \\
(2.62)\end{array}$ & $\begin{array}{c}6.56 \\
(2.56)\end{array}$ & $\begin{array}{c}6.67 \\
(2.58)\end{array}$ & $\begin{array}{c}6.44 \\
(2.54)\end{array}$ & $\begin{array}{c}5.78 \\
(2.40)\end{array}$ & $\begin{array}{r}5.22 \\
(2.27\end{array}$ \\
\hline & SED & NS & 0.41 & 0.38 & 0.04 & 0.44 & 0.46 & 0.48 & 0.47 & 0.52 & 0.62 \\
\hline & $\mathrm{CD}<0.5 \%$ & & 0.89 & 0.83 & 0.10 & 0.95 & 0.99 & 0.99 & 1.01 & 1.11 & 1.33 \\
\hline
\end{tabular}

Values in parentheses are square root transformed values 
Table.2 Evaluation of green insecticides for the management of Gram podborer, H. armigera in Pigeonpea (Kharif 2019)

\begin{tabular}{|c|c|c|c|c|c|c|c|c|c|c|c|}
\hline \multirow[t]{3}{*}{ Treatments } & \multirow{3}{*}{$\begin{array}{l}\text { Dose } \\
\text { per litre }\end{array}$} & \multicolumn{10}{|c|}{ No. of larvae per plant } \\
\hline & & \multicolumn{4}{|c|}{ I spray } & \multicolumn{3}{|c|}{ II spray } & \multicolumn{3}{|c|}{ III spray } \\
\hline & & $\begin{array}{l}\text { Preco } \\
\text { unt }\end{array}$ & 3DAT & 7 DAT & $\begin{array}{l}10 \\
\text { DAT }\end{array}$ & 3DAT & 7 DAT & $\begin{array}{l}10 \\
\text { DAT }\end{array}$ & 3DAT & 7 DAT & $\begin{array}{l}10 \\
\text { DAT }\end{array}$ \\
\hline $\mathbf{T}_{1:}$ Bt Kurstaki & $1.0 \mathrm{~g}$ & 3.63 & $\begin{array}{c}2.83 \\
(1.68)\end{array}$ & $\begin{array}{c}3.03 \\
(1.74)\end{array}$ & $\begin{array}{c}3.93 \\
(1.98)\end{array}$ & $\begin{array}{c}3.28 \\
(2.91)\end{array}$ & $\begin{array}{c}2.53 \\
(1.59)\end{array}$ & $\begin{array}{c}2.53 \\
(1.59)\end{array}$ & $\begin{array}{c}2.31 \\
(2.52)\end{array}$ & $\begin{array}{c}1.74 \\
(2.36)\end{array}$ & $\begin{array}{c}1.39 \\
(2.32)\end{array}$ \\
\hline $\mathrm{T}_{2}:$ Beauveria bassiana & $5.0 \mathrm{~g}$ & 3.50 & $\begin{array}{c}2.93 \\
(1.71)\end{array}$ & $\begin{array}{c}3.71 \\
(1.92)\end{array}$ & $\begin{array}{c}4.03 \\
(2.01)\end{array}$ & $\begin{array}{c}3.54 \\
(3.03)\end{array}$ & $\begin{array}{c}2.73 \\
(1.65)\end{array}$ & $\begin{array}{c}2.73 \\
(1.65)\end{array}$ & $\begin{array}{c}2.53 \\
(2.71)\end{array}$ & $\begin{array}{c}2.22 \\
(2.64)\end{array}$ & $\begin{array}{c}1.66 \\
(2.58)\end{array}$ \\
\hline $\mathbf{T}_{3}:$ Metarhizium anisopliae & $5.0 \mathrm{~g}$ & 3.50 & $\begin{array}{c}3.17 \\
(1.78)\end{array}$ & $\begin{array}{c}3.90 \\
(1.97)\end{array}$ & $\begin{array}{c}4.36 \\
(2.09)\end{array}$ & $\begin{array}{c}4.01 \\
(3.30)\end{array}$ & $\begin{array}{c}3.73 \\
(1.93)\end{array}$ & $\begin{array}{c}3.73 \\
(1.93)\end{array}$ & $\begin{array}{c}3.86 \\
(2.66)\end{array}$ & $\begin{array}{c}2.43 \\
(2.52)\end{array}$ & $\begin{array}{c}2.32 \\
(2.47)\end{array}$ \\
\hline $\mathbf{T}_{4:}$ Lecanicilium lecanii & $5.0 \mathrm{~g}$ & 3.80 & $\begin{array}{c}3.47 \\
(1.85)\end{array}$ & $\begin{array}{c}4.06 \\
(2.00)\end{array}$ & $\begin{array}{c}4.26 \\
(2.06)\end{array}$ & $\begin{array}{c}3.79 \\
(3.15)\end{array}$ & $\begin{array}{c}3.54 \\
(1.88)\end{array}$ & $\begin{array}{c}3.54 \\
(1.85)\end{array}$ & $\begin{array}{c}3.32 \\
(2.37)\end{array}$ & $\begin{array}{c}2.88 \\
(2.33)\end{array}$ & $\begin{array}{c}1.88 \\
(2.49)\end{array}$ \\
\hline$T_{5}:$ Azadirachtin 1500 ppm & $5.0 \mathrm{ml}$ & 3.47 & $\begin{array}{c}3.07 \\
(1.75)\end{array}$ & $\begin{array}{c}3.80 \\
(1.95)\end{array}$ & $\begin{array}{c}4.16 \\
(2.04)\end{array}$ & $\begin{array}{c}3.73 \\
(3.17)\end{array}$ & $\begin{array}{c}2.77 \\
(1.66)\end{array}$ & $\begin{array}{c}2.87 \\
(1.69)\end{array}$ & $\begin{array}{c}3.62 \\
(2.52)\end{array}$ & $\begin{array}{c}2.19 \\
(2.47)\end{array}$ & $\begin{array}{c}1.87 \\
(2.50)\end{array}$ \\
\hline $\begin{array}{l}\mathrm{T}_{6:} \text { Chlorantraniliprole } 18.5 \mathrm{SC} \\
30 \mathrm{~g} \text { a.i/ha }>\text { Flubendiamide } 480 \\
\text { SC @ } 30 \mathrm{~g} \text { a.i/ha> dimethoate }\end{array}$ & - & 3.73 & $\begin{array}{c}0.80 \\
(0.89)\end{array}$ & $\begin{array}{c}1.17 \\
(1.08)\end{array}$ & $\begin{array}{c}2.30 \\
(1.49)\end{array}$ & $\begin{array}{c}1.63 \\
(1.68)\end{array}$ & $\begin{array}{c}0.60 \\
(0.77)\end{array}$ & $\begin{array}{c}0.60 \\
(0.77)\end{array}$ & $\begin{array}{c}0.78 \\
(1.48)\end{array}$ & $\begin{array}{c}0.10 \\
(1.59)\end{array}$ & $\begin{array}{c}0.22 \\
(1.69)\end{array}$ \\
\hline $\mathrm{T}_{7}:$ Untreated check & - & 4.40 & $\begin{array}{c}5.17 \\
(2.27)\end{array}$ & $\begin{array}{c}6.71 \\
(2.59)\end{array}$ & $\begin{array}{c}6.83 \\
(2.60)\end{array}$ & $\begin{array}{c}7.14 \\
(5.08)\end{array}$ & $\begin{array}{c}7.66 \\
(2.76)\end{array}$ & $\begin{array}{c}6.96 \\
(2.64)\end{array}$ & $\begin{array}{c}6.64 \\
(3.33)\end{array}$ & $\begin{array}{c}5.78 \\
(3.37)\end{array}$ & $\begin{array}{c}5.53 \\
(3.30)\end{array}$ \\
\hline & SED & NS & 0.39 & 0.44 & 0.56 & 0.55 & 0.49 & 0.32 & 0.90 & 0.48 & 0.49 \\
\hline & $\mathrm{CD}<0.5 \%$ & & 0.85 & 0.96 & 1.22 & 1.21 & 1.07 & 0.70 & 1.97 & 1.04 & 1.08 \\
\hline
\end{tabular}

Values in parentheses are square root transformed values 
Table.3 Evaluation of green insecticides for the management of Gram podborer damage and yield

\begin{tabular}{|c|c|c|c|c|c|c|c|c|c|}
\hline \multirow[t]{2}{*}{ Treatments } & \multirow{2}{*}{$\begin{array}{l}\text { Dose } \\
\text { per litre }\end{array}$} & \multicolumn{3}{|c|}{ Per cent pod damage } & \multirow{2}{*}{$\begin{array}{l}\text { Per cent } \\
\text { reduction } \\
\text { over } \\
\text { control }\end{array}$} & \multicolumn{3}{|c|}{ Yield (Kg/ha) } & \multirow{2}{*}{$\begin{array}{l}\text { Percent } \\
\text { Yield } \\
\text { increase over } \\
\text { check }\end{array}$} \\
\hline & & 2018 & 2019 & Mean & & 2018 & 2019 & Mean & \\
\hline $\mathbf{T}_{1:}$ Bt Kurstaki & & $\begin{array}{c}36.67 \\
(23.90)\end{array}$ & $\begin{array}{c}10.67 \\
(18.81)\end{array}$ & 23.67 & 47.90 & 858.3 & 963.3 & 910.8 & 39.08 \\
\hline $\mathrm{T}_{2}:$ Beauveria bassiana & $1.0 \mathrm{~g}$ & $\begin{array}{c}36.67 \\
(37.22)\end{array}$ & $\begin{array}{c}14.67 \\
(22.19)\end{array}$ & 25.67 & 43.50 & 820.0 & 976.0 & 898.0 & 37.09 \\
\hline $\mathbf{T}_{3}:$ Metarhizium anisopliae & $5.0 \mathrm{~g}$ & $\begin{array}{c}46.67 \\
(41.12)\end{array}$ & $\begin{array}{c}28.00 \\
(31.91)\end{array}$ & 37.33 & 17.84 & 798.3 & 843.3 & 820.8 & 25.31 \\
\hline $\mathbf{T}_{4:}$ Lecanicilium lecanii & $5.0 \mathrm{~g}$ & $\begin{array}{c}40.00 \\
(39.20)\end{array}$ & $\begin{array}{c}22.67 \\
(28.41)\end{array}$ & 31.33 & 31.05 & 780.0 & 878.0 & 829.0 & 26.56 \\
\hline$T_{5}:$ Azadirachtin $1500 \mathrm{ppm}$ & $5.0 \mathrm{~g}$ & $\begin{array}{c}40.00 \\
(39.20)\end{array}$ & $\begin{array}{c}18.67 \\
(25.57)\end{array}$ & 29.33 & 35.43 & 826.0 & 870.0 & 848.0 & 29.46 \\
\hline $\begin{array}{l}\mathrm{T}_{6:} \text { Chlorantraniliprole } 18.5 \mathrm{SC} \\
30 \mathrm{~g} \text { a.i/ha >Flubendiamide } 480 \\
\mathrm{SC} @ 30 \mathrm{~g} \text { a.i/ha> dimethoate }\end{array}$ & - & $\begin{array}{c}13.33 \\
(21.32)\end{array}$ & $\begin{array}{c}5.33 \\
(13.17)\end{array}$ & 9.33 & 79.46 & 1098.2 & 1193.3 & 1145.7 & 74.90 \\
\hline $\mathbf{T}_{7}:$ Untreated check & - & $\begin{array}{c}65.56 \\
(54.16)\end{array}$ & $\begin{array}{c}25.33 \\
(30.12)\end{array}$ & 45.44 & - & 610.0 & 700.0 & 655.0 & - \\
\hline & SED & 4.26 & 3.76 & & & & & & \\
\hline & $\mathrm{CD}<0.5 \%$ & 9.14 & 8.19 & & & & & & \\
\hline
\end{tabular}

Values in parentheses are arc sine transformed values 
Pandey and Das (2016) reported that among the biopesticides, Beauveria bassiana@1 litre per ha was found to be most effective biopesticide as it recorded lowest larval population (6.68 larvae/5 plants).From the present study, it may be concluded among the green insecticides tested, the application of $B t$ varKurstaki@1.0 g per 1 was found effective in reducing the larval population as well as the pod damage caused by gram podborer, $H$. armigera for obtaining higher grain yield and can find place in eco-friendly approaches for pod borer management so as to avoid the insecticide resistance. At the same time, for immediate reduction sequential application of Chlorantraniliprole 18.5 SC $30 \mathrm{~g}$ a.i per ha followed by Flubendiamide 480 SC @30 g a.i per ha and Deltamethrin 2.8 EC@ $12.5 \mathrm{~g}$ a.i per ha may be adopted.

\section{Acknowledgement}

The authors are very much grateful to Indian Institute of Pulses Research, Kanpur for providing financial assistance and also to Tamil Nadu Agricultural University, Coimbatore for providing opportunity to work in All-India Co-ordinated Research Project on Pigeonpea at Agricultural Research Station, Virinjipuram.

\section{References}

Ankali, S, Jadhav, M, Jadhav, Y.T. and Barkade D.P. 2011. Study of relative toxicity of synthetic insecticides and biopesticides to Maruca vitrata on pigeonpea. International Journal of plant protection, 4(1):156-157.

Gomez, K.A and Gomez A.A.1984. Statistical procedures for Agricultural Research. John Wiley and sons, New York, 207$215 \mathrm{pp}$.

Gundannavar, K.P, Lingappa, S and Giraddi, R.S.2004. Biorational approaches for the management of podborer in pigeonpea ecosystem. Karnataka Journal of Agricultural Sciences, 17(3):597-599

Jayashri, U, Sarkate, M.B, Tuoat, P.P and Chavhan, K.R. 2008. Comparative performance of different insecticides against $H$. armigera and E. atomosa damage in pigeonpea (Cajanus cajan 1.) at harvest. Crop Research (Hisar), 36(1/3):299-301.

Jeyarani, S and Karuppuchamy, P. 2010. Investigations on the enhancing efficacy of granulovirus on nucleopolyhedrovirus of Helicoverpa armigera (Hubner). Journal of biopesticides, 3(1):172-176.

Kulat, S. S and Nimbalkar, S.A. 2000. Field evaluation of biopesticides and neem seed wxtract against podborer Heliothis armigera on Pigeonpea. PKV Research Journal, 24(1):26-29.

Minja, E, Shanower, T.G, Silim, S.N and Karuru, O. 2000. Efficacy of different insecticides for pigeonpea pest management in Kenya. International chickpea and Pigeonpea News letter, 7:53-55

Mohapatra, S.D and Srivastava, C.P. 2008. Toxicity of biorational insecticides against spotted podborer, Maruca vitrata (Geyer) in short duration pigeonpea. Indian Journal of Entomology, 70(1):61-63.

Naresh, J.S and Singh, J.1984. Population dynamics and damage of insect pests in flowering pigeonpea (Cajanus cajan (L.). Indian Journal of Entomology, 46(4):412-420.

Pandey, S.A. and S.B. Das. 2016. Evaluation of biopesticides against gram podborer, Helicoverpa armigera (hub.) on pigeonpea. Legume Research, 39 (3):479-481.

Shanower, T.G., Romeis, J and Minja E.M. 1999. Insect pests of pigeonpea and their management. Ann.Rev.ent., 44,77- 
96

Sharma, H.C.1998. Bionomics, host plant resistance and management of legume pod borer, Maruca vitrata - a review. Crop Protection, 17: 373-386

Singh, S.S and Yadav, S.K. 2006. Efficacy and economics of some modern insecticides, bio insecticides and neembased formulations against pod borer, Helicoverpa armigera, in pigeon pea. Indian Journal of Entomology, 68 (2): 139-143.

Sreekanth, $\mathbf{M}$ and Seshamahalakshmi, M. 2011. Studies on relative toxicity of biopesticides to Helicoverpa armigera (Hubner) and Maruca vitrata (Geyer) on pigeonpea (Cajanus cajan L.) $J$ Biopest. 5(2):191-195

Sushil Kumar Chauhan, R and Roshan Lal. 2009. Evaluation of native strains of Bacillus thuringiensis var. kurstaki against Helicoverpa armigera (Hubner) on pigeonpea. Journal of Insect Science, 22(2): 139-143

Yadav, G.S and Dahiya, B. 2004. Evaluation of new insecticides/ chemicals against pod borer and pod fly on pigeonpea. Annals of Biology, 20(1): 55-56.

\section{How to cite this article:}

Thilagam, P., D. Dinakaran and Gopikrishnan, A. 2020. Evaluation of Green Insecticides against Gram Podborer, Helicoverpa armigera (Hubner) in Pigeonpea (Cajanus cajan L.). Int.J.Curr.Microbiol.App.Sci. 9(08): 3117-3124. doi: https://doi.org/10.20546/ijcmas.2020.908.354 